\title{
Developing an Insight into the Art and Science of Well-being
}

\author{
Kiran Rani ${ }^{1}$, Ashish Kumar Dhawan ${ }^{2}$ \\ ${ }^{1}$ Senior Research Fellow, Department of Education, Maharshi Dayanand University, Rohtak, Haryana, India \\ ${ }^{2}$ M.Sc. (Physics), M.Ed, Maharshi Dayanand University, Rohtak, Haryana, India
}

\begin{abstract}
The concept of well-being has remained in discussion since the times of philosophers like Aristotle, as it may be considered, in many respects, the essence of human existence. In recent times, well-being has moved from the realm of philosophy to that of science and has attracted many a researchers into the search of what contributes to the state of well-being of people. This has enabled a new understanding of the factors that both influence and constitute well-being. Present paper attempts to develop an insight into those factors that influence and constitute well-being viz. Autonomy, Environmental mastery, Personal Growth, Positive Relations, Purpose in life, Self-acceptance etc. The science of well-being suggests that for experiencing good feelings, people need to have a sense of individual vitality to undertake activities which they perceive to be meaningful, engaging, and make them feel competent and autonomous. It is also crucial to have resourcefulness to help cope when things go wrong, acceptance towards one's flaws, taking the failures and defeats in a sportsman spirit and be resilient to changes beyond their immediate control. The paper further suggests the measures a teacher can adopt to boost the feeling of well-being among his/her students.
\end{abstract}

Keywords: Well-being, Autonomy, Environmental Mastery, Personal Growth, Positive Relations, Purpose in Life, Self -acceptance

\section{Concept of Well-Being}

The concept of well-being has remained in discussion since the times of philosophers like Aristotle, as it may be considered, in many respects, the essence of human existence. Generally speaking, wellness refers to the state of being comfortable, healthy and happy. It is associated with various aspects of physical, mental, and social well-being that extend beyond the traditional definition of health. The state of well-being encompasses the choices and activities aimed at achieving physical vitality, mental promptness, social satisfaction, a sense of accomplishment and personal fulfilment. It involves a sense of contentment because one is doing something that fully uses one's abilities and talents. The feeling of having a purpose in life and connection with others are also contributors to the idea of well-being. Huppert et al (2005) construe well-being as 'life going well, characterised by health and vitality, by happiness, creativity and fulfilment'. They also stress that well-being is more than pleasant emotions because it must also encompass human resilience - the ability to thrive in the face of adversity.

\section{Contour of Well-Being}

The extensive literature aimed at defining positive psychological functioning includes such perspectives as Maslow's (1968) conception of self-actualization, Rogers's (1961) view of the fully functioning person, Jung's (1933; Von Franz, 1964) formulation of individuation, and Allport's (1961) conception of maturity. A further domain of theory for defining psychological well-being follows from life span developmental perspectives, which emphasize the differing challenges confronted at various phases of the life cycle. Included here are Erikson's (1959) psychosocial stags model, Buhler's basic life tendencies that work toward the fulfilment of life (Buhler, 1935; Buhler \& Massarik, 1968), and Neugarten's $(1968,1973)$ descriptions of personality change in adulthood and old age. Jahoda's (1958) positive criteria of mental health, generated to replace definitions of wellbeing as the absence of illness, also offer extensive descriptions of what it means to be in good psychological health. These perspectives have had meager empirical impact (see Ryff, 1982, 1985). (Ryff, 1989)

Ryff (1989) identified some recurring factors affecting Wellbeing in different theories and conducted an empirical study and found these factors strongly correlated with the over all well-being of individuals. These factors include:

Self-acceptance: The most recurring criterion of well-being in the previous perspectives is that of the individual's sense of self-acceptance. This is deemed as a central feature of mental health as well as a characteristic of self-actualization, optimal functioning and maturity. Life span theories also emphasize acceptance of self along with acceptance for one's past life. Thus, holding positive attitude towards oneself emerges as a central characteristic of positive psychological functioning.

Positive relations with others: Many of the preceding theories emphasize the importance of warm, trusting interpersonal relations. The ability to love is viewed as a central component of mental health. Self-actualizers are described as having strong feelings of empathy and affection for all human beings and as being capable of greater love, deeper friendship, and more complete identification with others. Warm relating to others is posed as a criterion of maturity. Adult developmental stage theories also emphasize the achievement of close unions with others (intimacy) and the guidance and direction of others (generativity). Thus, the importance of positive relations with others is repeatedly stressed in these conceptions of psychological wellbeing.

Autonomy: There is considerable emphasis in the prior literature on such qualities as self-determination, independence, and the regulation of behavior from within. Self-actualizers, for example, are described as showing 


\section{International Journal of Science and Research (IJSR) \\ ISSN (Online): 2319-7064}

Index Copernicus Value (2015): 78.96 | Impact Factor (2015): 6.391

autonomous functioning and resistance to enculturation. The fully functioning person is also described as having an internal locus of evaluation, whereby one does not look to others for approval, but evaluates oneself by personal standards. Individuation is seen to involve a deliverance from convention, in which the person no longer clings to the collective fears, beliefs, and laws of the masses. The process of turning inward in the later years is also seen by life span developmentalists to give the person a sense of freedom from the norms governing everyday life.

Autonomy reflects the individual's perception that his or her behavior is initiated and regulated by a personal rather than by an environmental force. He himself is the origin of his behavior and the causal source of one's behavior does not lie in an environmental force - that an individual's behavior has been energized, coerced, or seduced by desired environmental outcomes.

Environmental mastery: The individual's ability to choose or create environments suitable to his or her psychical conditions is deemed as a characteristic of mental health. Maturity is seen to require participation in a significant sphere of activity outside of self. Life span development is also described as requiring the ability to manipulate and control complex environments. These theories emphasize one's ability to advance in the world and change it creatively through physical or mental activities. Successful aging also emphasizes the extent to which the individual takes advantage of environmental opportunities. These combined perspectives suggest that active participation in and mastery of the environment are important ingredients of an integrated framework of positive psychological functioning.

Purpose in life: Mental health is denned to include beliefs that give one the feeling there is purpose in and meaning to life. The definition of maturity also emphasizes a clear comprehension of life's purpose, a sense of directedness, and intentionality. The life span developmental theories refer to a variety of changing purposes or goals in life, such as being productive and creative or achieving emotional integration in later life. Thus, one who functions positively has goals, intentions, and a sense of direction, all of which contribute to the feeling that life is meaningful.

Personal growth: Optimal psychological functioning requires not only that one achieve the prior characteristics, but also that one continue to develop one's potential, to grow and expand as a person. The need to actualize oneself and realize one's potentialities is central to the clinical perspectives on personal growth. Openness to experience, for example, is a key characteristic of the fully functioning person. Such an individual is continually developing and becoming, rather than achieving a fixed state wherein all problems are solved. Life span theories also give explicit emphasis to continued growth and the confronting of new challenges or tasks at different periods of life. Thus, continued personal growth and self-realization is a prominent theme in the aforementioned theories. It may also be the dimension of well-being that comes closest to Aristotle's notion of eudaimonia. In sum, the integration of mental health, clinical, and life span developmental theories points to multiple converging aspects of positive psychological functioning.

\section{Measures a Teacher can adopt to promote Well-being among Students}

Ensuring well-being among youth is not the responsibility of parents and counsellors only. It is the responsibility of the society as a whole in which teachers have a very crucial role to play. To ensure well-being of the students, a teacher, during the interactions with students can strengthen the factors responsible for over all well-being that have been discussed above in detail. Sheer knowledge of these factors, willingness to ensure well-being among students and awareness of the present state of physical and mental health of the students may serve as the building blocks of the wellbeing of the students.

A teacher must keep vigil on the status of physical and mental health of the students by checking the following points:

- A teacher should know how a student feels about himself, including his physical appearance and achievements and failures in life his. What is his attitude towards present life and the past life. He should also find out what his perspective is on the issues he faces in everyday life to know his level of self-acceptance. If teacher is able to recognise the access of negative feelings in the student viz fears, concerns, doubts, shame regarding himself and his past or present life, teacher should counsel the student to change his perspective. He may also take help of parents and counsellors.

- Positive relations with others aspect of a student can be easily found out by the teacher by observing the pattern of interaction with other friends. Points to be taken into consideration here are how many friends a student has? Does he trust them or not? In general what kind of bonding he has with people around him including his parents, siblings, class-mates, seniors, juniors, teachers and the non-teaching staff? Whether he feels happy in their company or not? These points will indicate his level of adjustment and the kind of relations he has with others. If the level of positive social interactions is low, then the teacher needs to find out the causes and adopt corrective measures such as counselling.

- A teacher should be aware of the driving force of the students' behaviour. Whether the student is reading because of the fear of the teacher and the exams or because he finds reading interesting? How he feels while reading? Is reading a liberating experience for him or a dull task performed under coercion? He should also know whether his over all decisions are governed by his will or they are directed/forced/seduced by some environmental factor and what influences him/her the most. These are the points through which autonomy aspect can be checked. If the autonomy aspect is lacking, teacher should try to inculcate curiosity and interest to promote engagement of student in academic activities by removing the causes of lack of internal motivation to perform desirable activities.

- Environmental mastery means the student's ability to choose or create environments suitable to his or her 


\section{International Journal of Science and Research (IJSR) \\ ISSN (Online): 2319-7064 \\ Index Copernicus Value (2015): 78.96 | Impact Factor (2015): 6.391}

psychical conditions which is deemed as a characteristic of mental health. Teacher can check the problem areas in this aspect by checking pattern of presence in the classroom, not only the physical presence, but also the mental presence. This may be an important indicator of his mastery over the school environments.

- Another measure of well-being is a clear comprehension of life's purpose, a sense of directedness, and intentionality. A teacher may develop a comprehension of this aspect of student's well- being by asking him what does wish to achieve in his life and whether or not he is moving ahead in that direction or not? If not; then why not and counselling him to enable his advancement in the desired and desirable direction.

- The need to actualize oneself and realize one's potentialities is central to the clinical perspectives on personal growth. It includes indulging in the activities that produce a fulfilling effect in an individual but may or may not be socially or professionally useful, viz learning to play some musical instrument or singing or some other activity. The teacher may develop awareness about this aspect by knowing the aspirations of the child and the gaps.

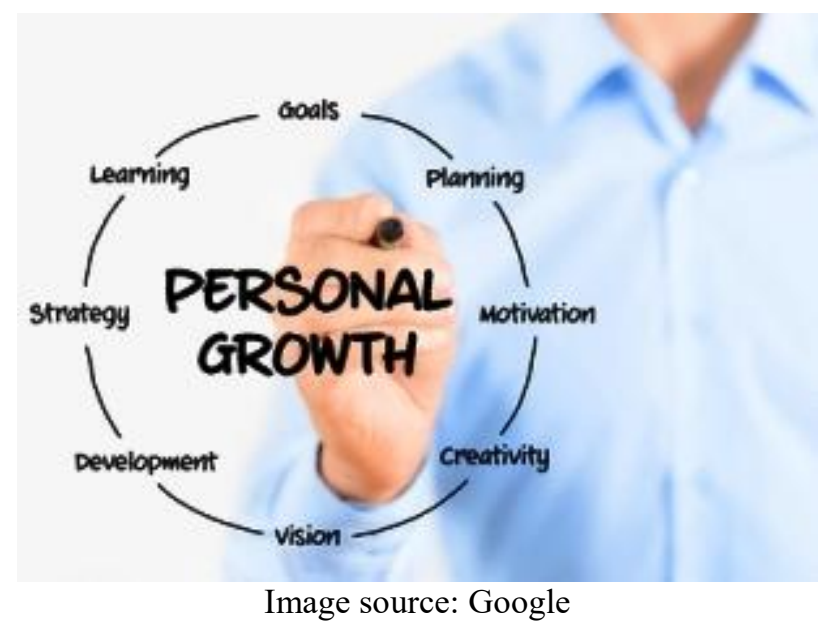

\section{Conclusion}

The crux of the matter is that a teacher is the most important pillar to ensure well-being of the students, especially in a country like India where a huge chunk of the population is still illiterate and lives below poverty line and a huge number of students are the First-generation learners. Keeping in mind the Ryff's measures of well-being a teacher can watch the presence and absence of well-being among students at least in the academic arena.

\section{References}

[1] Huppert, F. A. (2005) Positive mental health in individuals and populations. In The Science of WellBeing (eds F. A. Huppert, N. Baylis \& B. Keverne), pp. 307-340. Oxford University Press.

[2] Image, Personal Growth. https://www.google.co.in/search?q=personal+growth + im ages \&espv $=2 \&$ biw $=1366 \& b i h=662 \&$ tbm $=i \operatorname{sch} \&$ tbo $=u \&$ source $=$ univ $\&$ sa $=$ X\&ved $=0$ ahUKEwis9cXDq6LQAhVF $\underline{\text { sY8KHQJZAJkQ7AkINA\#imgrc=LvfQNrrHJEJhRM\%3 }}$ $\underline{\mathrm{A}}$

[3] Ryff, C. D., (1989). Happiness Is Everything, or Is It? Explorations on the Meaning of Psychological WellBeing, Journal of Personality and Social Psychology, Vol. 57(6), pp1069-1081. Retrieved from http://coursedelivery.org/write/wpcontent/uploads/2015/02/2-Happiness-is-everything-oris-it.pdf

\section{Author Profile}

Kiran Rani is Senior Research Fellow in the Department of Education, Maharshi Dayanand University, Rohtak, Haryana. Her areas of Specialization are ICT, Teacher Education, Educational and Vocational Guidance and Teaching of English

Ashish Kumar Dhawan is M.Sc. (Physics), M.Ed. His area of specialisation is Teaching of Physical Science, India 